\title{
Chapter 9 \\ Leading Transformation with Digital Innovations in Schools and Universities: Beyond Adoption
}

\author{
Eugene Kowch
}

\subsection{Introduction}

Innovation doesn't happen in a vacuum but requires openness and interactions between systems and their environments. This is also very much the case for education. (OECD 2016, p. 3)

Digital technologies do not transform a learning organization in isolation, but they can offer high potentials for constant-flux schools and university contexts. In this chapter, we argue that leading digital transformation in the learning organization first requires different leadership approaches and then different organization structures to allow more autonomous, team-based digital innovation efforts across education ecosystems (Kowch 2018a). Only then can schools and universities adapt to digital innovation experiments that can truly transform their products and processes (learners with better lives). First, we explore how existing formal leadership ideas to "adopt" education technologies have been confused with true innovation to offer leaders and innovators a different path for conceptualizing great digital innovation as a complex mix of experimental, evidence-informed, risk-taking done by networks of teams. Daimler-Benz cannot transform the company by inventing a driverless car. Yet in their past they have transformed the company by changing the processes and products of the organization by integrating ideals for safe driving with vast technological innovations. Innovation in education systems means much more than invention, technology or technology adoption alone.

Contemporary Education change scholars warn that schools and universities cannot lead such transformation because we fail to create adaptable organizations that can transform with our digital innovations (Hargreaves and Shirley 2012). Instead, we focus on piecemeal, microscale change in learning while making huge technology investments in organizations (Fullan and Kirtman 2016), while the

E. Kowch $(\triangle)$

University of Calgary, Calgary, Canada

e-mail: ekowch@ucalgary.ca

D. Ifenthaler et al. (eds.), Digital Transformation of Learning Organizations, 
OECD (2016) warns that massive global education technology investments have failed to generate proportional learning improvements for learners.

The problem is that educators need knowledge to organize and to lead digital innovation teams differently today. Ifenthaler and Egloffstein (2020) remind that digital technology integration is an important mission for every business, organization, or institution not only for communication, administration, and management but also for learning and instruction/teaching (p. 302). However, with artificial intelligence, Big Data, smart classrooms (Ifenthaler 2017), and service robots (Kowch 2020) arriving in the near horizon to help teaching and learning, digital innovation teams need guides for leading a more integrated approach to leading, learning innovation work that offers a better chance to transform the learning organizations.

Our understanding of education ecosystems has changed a lot from historical presumptions of stable, linear role-in-function systems (only dead systems are stable) to unstable systems with complex, interconnected dynamics where a change in one part of the system affects all other parts of it (Schwandt and Sabla 2007; Hazy and Uhl-Bien 2015). Too often misunderstood by university leaders as "apps" for achieving vaguely defined "transformation" adoption and buy-in, most educational technology projects live short, hectic lives. Here we offer theory and practical guidelines for digital innovation leaders who guide integrated solutions that can, with the right leadership and organization, truly transform and sustain a school or university.

Section 9.2 explores why classic, more formal approaches to leading and organizing our work constrains the adaptive spaces necessary for digital innovators and leaders interested in real transformation. Section 9.3 outlines how (less formal) leader and organization approaches can lead and organize work differently as ecologies of innovation thriving in more open organizations. We demonstrate how and why digital innovation teams have a better chance to impact deep school and university change by forming highly capable relational teams within more adaptive organization structures or "homes" for that important work. The final section offers theory and practical guidelines for networked digital innovation team members and leaders whose experiments can be better engines for genuine, system-wide education organization transformation.

\subsection{Formal Leaders in Formal Organizations: Limiting Space for Innovation}

Classical formal leader epistemologies fit tongue-in-groove with formal organization epistemologies (Clegg et al. 2011). For digital innovators (all innovators) today, that classic way of knowing technology, education systems and leadership is a toxic combination that unconsciously limits individual and team innovator potential for school or university transformation. In this section, we explore four important concepts and features for leading and managing digitization and change in education systems today: people, power, systems, and change/innovation (Hallinger and Heck 
2002). Senge et al. (2000) remind us that informal leaders do the right thing, while formal leaders do things right (as process managers).

\subsubsection{Formal Leadership: Doing Things Right with People, Power, Systems, and Change}

For over a century, scholars and practitioners in education have struggled to define educational leadership but many agree with Yukl's (1994) meaning:

Most definitions of leadership reflect the assumption that it involves a social influence process by one person (or group) to structure the activities and relationships or in a group or organization. (p. 3)

Formal leaders operate within the confines of roles and vertical power lines forming limited paths for transactions usually aimed at improving work flow efficiencies. Formal leaders consider the utility of a technology in terms of how it will improve functional efficiency from subordinates working together, but from different specialist 'silos'. In the last century (1900 to 1950), Taylor's scientific management theory defined formal leadership first as a set of predictable cause-effect, rule-based work relations between managers supervising employees in steady-state systems (organizations or institutions) in terms that do not describe the hyper-connected leading and working world of education organizations, yet you can find many scientific managers in at any moment or context in education today. Scientific leaders think about the inputs, processes, and outcomes of work done by specialized-labor employees with an overall goal to apply psychology for improved organization (school, university) outputs-so social dynamics and worker humanity did not concern early formal leaders aiming for stability. Because change and innovation in a system introduces risk, formal leaders minimize experimentation, risk-taking, and innovation. Per the leadership of Henry Ford, innovation occurs "at the top" of traditional, formal closed systems (Enkel, Bogers \& Chesbrough 2020). Not all leaders are Bill Gates.

Formal leaders understand power as a commodity that is attributed to a position (rank) and aligned within a vertical power-over hierarchy designed to control scarce resources (Carlsen et al. 2020). Formal leader power is not earned, rather it is assigned by comparing the rank of a leader over managers and employees functioning within strict rules assigned by their specialization and functions in an institution (Hallinger and Heck 2002) so position in the organization pecking order matters as much as capability. Carlsen et al. (2020) charts and laments how entrenched leader ideas about positional power-over reduces creativity and isolates individuals from collectives while scientific leaders have also been critiqued for power-over tactics for their "obsession with tight, top down control leading to institutional dysfunction" (Maguire et al. 2006, p. 173). This researcher has found repeatedly that formal leaders are more common in schools and universities struggling not to function as industries.

Formal leaders also understand their institution's existence as a factory unto itself-consciously or not, formal leaders act within what they believe is a closed 
system with inputs, processes, and outputs bounded by the institutional rules, roles and operating policies associated with it (Schwandt and Szabla 2007). "Closed systems are considered to be isolated from their environment" as steady-state systems (Bertalanffy 1968, p. 38). When a university provost evaluates the efficiency of an online learning program and faculty using LMS (learning management software) data (discussion frequencies, grades, logged time online) alone, he or she is leading formally to improve core processes isolated within the organization. As a manager, he or she is "doing things right" by adopting a proven efficiency tool or mindset (Senge et al. 2000), not really considering the complexity of interconnected subsystems such as learner preferences, adult life contexts or even cultural learning histories that might have powerful effects on the success of such technological enhancements. This is a real problem for digital innovation teams in schools, where, for example, we know that good online learning technology could transform a failing face-to-face school into a thriving cyber charter school (Kowch 2009). But formal leaders care less about the complexity of social systems, working on good transaction efficiency in a closed system model without regard for technical, pedagogical, or even financial potentials offered by digital innovations, for example. Formal leadership reduces the project to linear, stable and closed work organizations that may never have existed, and that certainly do not exist in today's education reality.

Leading change is an important element in education leadership thinking and praxis, particularly when innovations are involved because innovation causes change, to an extent, in education organizations (Fullan 2015). Digital technologies are often the greatest sources of such change in our time. Still, formal education leaders approach changes from an industrial paradigm stance where a change to inputs, usually in terms of human or mechanical performance, is believed to result in predictable linear cause-effect desired outcomes (ideally) so most leaders today apply systems theory to adopt a technology by following predictable innovation S-Curves in the back of their mind (Fig. 9.1), aiming for a specific change. Because adoption can be forced or manipulated in vertical power orgnizations, formal leaders often lead change by (a) seeking "buy-in" among employees for a technologically enhanced process that will result in what they hope will be an organizational change (Rogers 1962) and by (b) hoping that a technology or "app" can and will change the organization (Visvizi et al. 2018). This linear cause-effect approach to change leadership and innovation has been harshly criticized by contemporary organization and education scholars, who have proven time and again that formal leaders mostly create "piecemeal" or incremental change in education systems by assuming linear, steady-state change parameters while ignoring human learning and socio-technological influences (Reigeluth and Duffy 2008). The result is often a change that does not sustain, or a technology that soon sits idle after considerable investment.

Today most education systemic change research involves linear thinking about organizations assumed in steady states (equilibrium), a false assumption that hinders necessary experimentation and knowledge exchanges needed to change a school (Cabrera and Cabrera 2019; Kowch 2019; Reigeluth and Duffy 2008). In fact, many of the authors in Springer's Systems Thinking and Change major refer- 


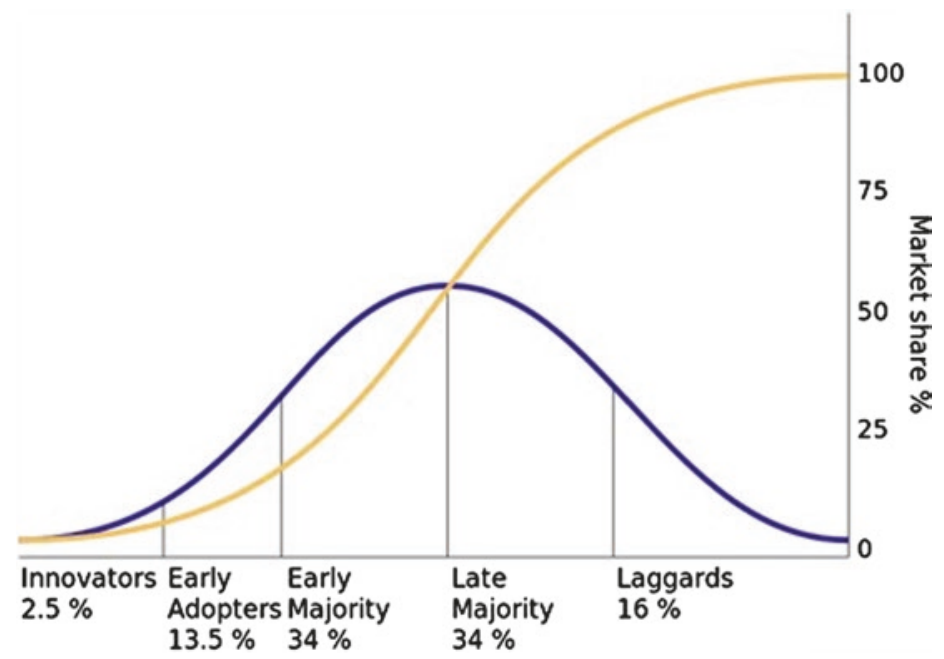

Fig. 9.1 Innovation Diffusion Curve (Rogers 1962). (Source: https://commons.wikimedia.org/ wiki/File:Diffusionofideas.PNG)

ence volume (Kowch 2020) write that when education technology is present, formal leadership falls short because formal leaders strive to maintain the status quo so as to avoid uncertainty brought by experimentation. That limits both risk-taking experiments and the adoption of innovations (Uhl-Bein et al. 2007), often reducing digitization to a matter of acquiring expertise that is directed to perform isolated (closed system) transactions without deep consideration of social factors in or beyond a school or education setting. By leading change as individuals (with variable practices), formal leaders depend on line management and role specialists believing that the purpose of the university or school is a pipeline for delivering individuals to society in systematic ways, so they wind up with limited success when engaging professions and the larger institutional community so essential to the sustained success of the change (Hargreaves and Shirley 2012).

\subsubsection{Formal Organization: Restricting Adaptive Space for Innovation}

An organization is a mental model for a structure that "houses" people doing work together in a "space" where a body of individuals work under a defined system of rules, assignments, procedures, and relationships designed to achieve identifiable objectives and goals (processes, products) (Greenwald 2008, p. 6). Formal organizations are highly structured, closed bureaucratic system arrangements of specialized people with vertical power responsibilities framed by clear rules/policy within isolated institutions most often acting with formal leaders adopt a closed system (Clegg 
et al. 2011, p. 148). People or laborers in a formal organization are assigned by position and function in a vertical hierarchy of functions (as in an organization chart), so their relations are prescribed by reporting lines (up and down). Working across departments, units, and specializations is challenging, if not impossible. For example, professor might have a good idea for a technological innovation to enhance instruction, for example, but because getting the technology information from the Information Technology department on the necessary instructional elements is not part of the IT person's "job" function per se, the instructional innovation stagnates. Post-COVID mandated instructors in universities, for example might find that an integrated student/instructor meeting booking system might just improve both learning and instruction, but in formal organizations with IT departments essentially operating out-of-house LMS packages, such an innovation cannot be specified technically or operationally because teaching is not connected to the design of the learning management system in-house. This formal organization or house is not designed for sharing information and ideas across lines of functional expertise.

The biggest challenge for next-generation or 21 st century organizations in education is that are rather formal bureaucracies - an industrial age concept critiqued for separating persons from their office in organizations characterized by hierarchical power and chains of command, meritocracy, and rule-based decision-making (Marion and Uhl-Bien 2001, 2007). These houses are not designed for the knowledge age, nor are their formal leaders. Bureaucracies like this exist mostly in formal organizations where leaders at the top of the organization structure possess power "over" people in positions below them and so on (Gu et al. 2018) along a "chain of command" enshrined in the organization structure that is the same if it is "bottom up" or "top down," limiting lateral influence beyond job functions.

So we argue that formal education organizations are closed systems that are always restricting heterogeneity or diversity that is essential for today's innovating organizations. Bureaucracies function to maintain formal organization structures, thus limiting engagement across schools, favoring top-down state investment and dependence on separate experts (i.e., Information Communiction Technology (ICT) experts, educational technologists, policy makers, financiers, disciplinarians in STEM) in the most brittle, change-resistant and unsustainable structures (Hargreaves and Shirley 2012). A common formal organization response to a lack of capability is to create mini-hierarchies or sub-structures (committees) of assigned experts resulting in organization charts that grow vertically-like Topsy. We need new mindsets to re-imagine collaborative, shared expertise and experimentation (often with digital processes) in more flexible organization forms (less formal) essential in the knowledge era.

Leading change in formal organizations means work by formal leaders in bureaucracies shaping cause-effect efforts without consideration of the constantflux environments outside education organizations. So education change leadership amounts, most often to micro level incremental, linear change efforts focused on a manageable part of the organization and not on the whole school, making transformation of that school (digitized or other) piecemeal and difficult to sustain (Reigeluth and Duffy 2008). 
Formal organizations are a "house" for digital innovation destined to occur by their very natures across a labyrinth of functions that bind expertise and restrict the space of the possible from often unconscious boundaries around people and by impeding risk-taking, experimentation and innovation, especially in education (Hargreaves and Shirley 2012).

For example, a recent case study (Downing 2018) of educational technology decision-making found a closed-system, power-over mandate from a government official to use (adopt) thousands of iPads in national following the top minister's consultation with expert vendors only. Adoption by most professors using the "super app" iPad innovation did not improve instruction, learning, or leadership. This study found that students only had slightly better access to the Internet. The product (learning) and adoption (instruction with iPads) did not change or transform the universities because their utility was only visible as in-house tools with limited connection to the lives and learning found among networks of instructors and students who were simultaneously and differently well-connected to the rest of the world. A new tool in a closed system that is not understood in terms of instruction and learning cultures is not an innovation, it is an adoption.

\subsection{Informal Leaders in Less Formal Organizations: Creating Adaptive Spaces}

The rapid and continuing development of technology in schools requires a new generation of leaders who to use these new tools to enhance their own productivity and decisionmaking activities and who understand the benefits of integrating technology into learning. (OECD 2016, p. 146)

\subsubsection{Informal Leadership: Doing the Right Things with People, Power, Systems, and Change}

From 1950 to 1970 , education leadership theorists realized that the work of educators and learners is not trait-dependent but rather that it is a more interdependent body of activity that is better conceptualized as a blend of social systems and human psychology. This was the dawn of the linear information processing (IP) or learning systems epoch when education administration scholars recognized that leadership by top-down actors in vertical power hierarchies depended a lot on specialized labor but also it depended on highly trained people who learn and live outside and inside the organization (Lord and Brown 2001). IP type leaders set goals and interventions to achieve prescribed learning and teaching outcomes as transactions in machine-like processes where people are considered human resource assets. Organizations (schools and universities) welcomed the integration of social dynamics elements to leadership thinking but individual hearts and hopes seemed left out 
of leader discourse and praxis. During this time, early educational technologists created teaching machines and explored mediated technology-enhanced learning hardware and software as well as instructional conditions.

By 1970, falling short of theory that predicted actual education leadership practice and reality, leadership theorists expanded their homogeneous integration of social systems, or team concepts so that leaders could consider values and ethics models as part of their work (Greenfield 1984), deepening leadership thinking and directing more action toward duties of care. By 1990, leadership scholars added individual ethos, ethics, and social values in less linear educating process models informed as well by critical social theory, leading to effective schools and instructional leadership models (Mitchell and Sackney 2011). The result was an improvement on formal leadership, but with a complex social dynamic in education such efforts resulted in school leader overload from tracking people and group performance within only slightly less bureaucratic conceptualizations disguised as instructional leadership (Hargreaves and Fink 2006). Results have been disappointing for years (Cuban 2001). At the same time, education technologists integrated Bandura's social learning into learning environment designs with personal-level computers and constructivist pedagogies.

From 1990 to 2020, more subjective and holistic open-system education models emerged for a newer generation of less formal leaders interested in leading from a premise that change is constant within and outside our education institutions. Learning from bio sciences, leadership research is finding that less formal, open systems are like living systems, and that natural scientists have proven that the only stable system on earth is a dead system (Cilliers 2000). So the formal leader/organization goal for stability and steady-state conditions seems a fallacy. Yet formal leadership and organizations still assume stable systems (Fullan 2015). By contrast, leaders in open systems are aware of their context in the environment, often creating flexible teams spanning institutions boundaries (Bertalanffy 1968; Kowch 2013). We have learned that open systems are in constant flux, so leaders can only understand them in the context of the environment or ecosystem (Gharajadedaghi 2011). This may seem like 'common sense', but few of our education planning, finance, policy or innovation processes consider more than the old steady-states or linear adoption strategies despite billions spent yearly to achieve 'transformations' at the education institution level. Transforming education organizations today requires far more informal leader approaches with informal "structuring" (organizing) so that change can happen at all-has a chance to happen. Yet look around you and you will find bureaucracies and formal leaders of position-galore. Similarly, living systems are the kind of open systems that can allow a thriving team (Capra 1997, 2002) to work across role boundaries. Leadership in open systems means managing upward or across relational elements such as organizations or teams that are, paradoxically, composed of individuals that co-connect (Barabasi 2003) and influence one another, tending toward far less formal, self-organizing with less formal order (p. 57). These connections can be described and understood as networks (Granovetter 1973) of codependent, less isolated people, yet informal leaders are not ad hoc.

Recently, a community reform/transformation leadership models have emerged to address the heterogeneity of individuals and people doing more than creating 
learning outcomes or stable budgets in the co-dependent work of instruction, including empowering people (Sergiovanni 1989; Leithwood and Jantzi 2005). Again, however we should remember that most research on leading education institution (organization) transformation offers little evidence that such institutional reform thinking has impacted learning achievement (Leithwood and Jantzi 2005), and we have found that reform/transformation leaders, labeled "transformational" leaders, often become "profoundly egoist" with their super-charge to empower employees toward better (Gronn 2002). Transformation language has exploded with innovation and change rhetoric where most transformation is actually found to be an incremental change in small subsystems at best (Kowch 2015), and so the term "transformation" remains popular and widely juxtaposed with "change." Less formal leaders in open education organizations, especially those working with digital innovators need a much better concept for leading deep change in education systems. This author considers transformation an organizational phenomenon where the process (teaching, administration, socializing) of education changes fundamentally, as does the product of education (learning outcomes, social impact). Today, education technologists are leaders in expensive "smart" learning, AI, and Big Data-informed learning environment designs for more self-directed, cloud-based, technologysupported infrastructures that may afford a reconfiguration of education leader thinking to include innovation and not just the adoption of innovations (Ifenthaler 2017; Spector and Ma 2019).

We must reconceptualize change, leadership and organizations to become better leaders now by evolving our leadership knowledge for a new context. (Levin and Fullan 2008)

This author has proposed a new, less formal paradigm for leaders working toward less formal and more integrated education system connecting IT, leadership, change, and learning environment by taking a complexity theory approach to create transformation through innovation (Kowch 2018), not transformation by technology adoption. The future of the educational technology subfield in education could depend on such a shift, because education technologist and leadership theory and practice may be overspecialized and disconnected from learning too much of the time (Kowch 2013b). Today, more relational and less formal co-dependent conceptualizations for leading education systems, power, labor, and change inform leaders "coaching" highly connected, constant-flux education network structures in more participative learning contexts via more distributed leadership (Hargreaves and Shirley 2012; Harris 2008). This is a refreshing idea for digital innovation team members who attract experts from across the organization for specific problemsolving and who work outside their traditional 'specialist' boxes to identify and to solve education system innovations that can (and do) change the product and processes in schools and universities in constant flux. However, artifacts of outdated education systems remain so that meritocracies (formal schools) can penalize informal collaboration, constraining people and chances that the organization could transform. We recommend starting digital transformation and organization transformations with informal digital innovation leadership in teams carefully designed to operate as subsystems within large formal organizations for this reason. Rome was not built in a day, and it is not structured for radical change- but change can evolve 
from subsystems experimenting with less formal leadership in more open system teams, skunkworks and cross-disciplinary structures or networks found or already operating within-Rome.

Defining complex adaptive leadership (Sect. 9.4), Uhl-Bein et al. (2007) reconfigure how informal leaders understand power - as a form of energy to facilitate, orchestrate, and share innovative ideas and outcomes throughout the organization where leader networks generate complex pro-innovation environments with complex (but knowable) dynamics and innovations-to-organization transference (p. 315). Less formal change leaders are similarly identified as "fourth way" change leaders who are able to focus on systemic and sustainable change with an inspiring, inclusive, and innovative mission (Hargreaves and Shirley 2012, p. 10), so for these leaders doing the right thing means "letting go" a little while building flexible organizations (houses) along with capable innovation teams. We need to assure that the "house" is be less formal, less structured so that it can handle change brought by collective innovation in an open network of people with the right knowledge and abilities to experiment and scale up innovation across our education systems today.

\subsubsection{Informal Organization: Creating Adaptive Spaces for Digital Innovation Teams with People, Power, Systems, and Change}

The challenge is to identify alternatives [to bureaucracy] and develop theories that account for them. It is not trivial. How can we improve upon, even replace, such a painstakingly well-developed concept of how human beings collectively best accomplish their objectives? (Child and McGrath 2001, p. 1136)

Human resources (people) relationships, knowledge, and skills related to innovation projects matter more in less formal social organizations that "house" dynamic work and innovation (Clegg et al. 2011). We know that leaders and leader collectives do more than lead (or follow) employees in schools and university organization "structures" or spaces and that they can work across departments and institutions with fewer formal network arrangements (Kowch 2015). We have previously explained that informal leadership is a shared or covalent influence (not power) network of relationships formed among people in open organizations with a purpose. Informal organizations are collections of people and leaders who are less separated from one another while working in constant-flux disequilibrium (Kowch 2015). Informal network "structures" have always been part of the setup of structures and flows of resources, power, and ideas in open, relational networked learning organizations (Kowch 2015), where people work together toward purposes (McLellan 2010); however, leadership theory has not recognized this informal "who you know" condition well enough. In these complex adaptive systems, change and innovation are much more likely, as is transformation (emergence) when the system members and leaders share influence (power) to imagine a different organization reality (process and product) through experimentation/innovation by doing more 
than adopting a technology in a linear fashion (Rogers 1962). A good example comes from COVID facing North American breweries that innovated their processes and products by "attracting" toward a more sustainable, caring organization purpose in the ecosystem. They adapted into hand sanitizer producers by experimenting with their alcohol production process.

In the next section, we elaborate on this informal kind of organization to offer guidelines for creating highly capable digital innovation network teams that experiment to create organization-changing experiments that can transform complex adaptive schools and universities into organizations with adaptive spaces. Now that we know how to share influence and create space for digital innovation teams, we need to know how to empower them so their experiments can lead to system-wide transformation more often.

\subsection{Toward a New Theory for Practicing Organization Transformation Through Digitization Innovations}

\subsubsection{Formal Innovation: An Addiction to Adopting Technology in Closed Systems}

Doing innovation work is challenging in formal organizations. Everett Rogers defines innovation as

... an idea, practice, or object that is perceived as new by an individual or other unit of adoption...[and] It matters little [...] whether or not an idea is "objectively" new as measured by the lapse of time since its first use or discovery. (Rogers 2003, p. 12)

Education change scholar Michael Fullan describes a wider context for education innovators who must consider at least three interdisciplinary innovation practice imperatives: (1) using new curriculum materials or technologies; (2) using new teaching strategies or activities, and (3) altering pedagogical assumptions. Educators attribute innovation diffusion models as models for incremental change (Licht et al. 2017). Sadly, a lot of education leaders do not go beyond simple education technology adoption practices because they do not understand the field or innovation well enough.

Innovation diffusion is an incremental approach to leading change and so too is the diffusion of innovations model (Christensen et al. 2008), because they both model linear adoptions of new ideas and technologies (such as distance education). Both are immensely popular formal models of closed-system, institution-bound, rule-based linear innovation based on rules in steady-state conditions in business; however, schools and universities are far from steady-state entities (Kowch 2020, in press). Christensen's model does not create disruption, rather it maps user preference value shifts that are usually accidental, so they do not apply well for change leadership in education.

Education change scholar Andy Hargreaves warns sharply that formal-approach education leaders have created a tragedy in schools by adopting innovations without 
considering whole school or community (ecosystem) benefits (Hargreaves and Shirley 2012, p. 24) by placing digital innovations in a box not well enough connected to the life of organization networks. Congruent recent meta-studies of literature in the educational technology field indicate that scholars are also "too technology-centered" (West and Borup 2014), so many sources point to a need for a paradigm shift in the field toward less linear, isolated technology adoption for a post-structural, integrated interdisciplinary leadership approach policy and computer science fields (Kowch 2013a, 2013b, 2019). Innovation, digital or not-that transforms an organization from a caterpillar to a butterfly, for example, means doing much more than adopting technology per Rogers' S-curve (1962) which is, in fact a linear market model constraining education system thinking today.

Limits to the formal diffusion model in education include its genesis as a market capture model and that model focuses on individuals motivated by peer example and personal safety (I had better do this) in early majority phases (Fig. 9.1), or uncritical employee compliance in phase 4-accounting for over $85 \%$ of total adoption of any innovation (Rogers 1962). Also, the innovation diffusion model presumes that static innovations (unchanging) and innovation bias (novelty) for individuals drive too much of the adoption unconsciously. As well, planners find the elastic time scale for adoption phases problematic (Zhai et al. 2018). Education technologists have also been preoccupied with the adoption of a good learning technology too much, say some (Bodily et al. 2019).

The innovation diffusion model works for leaders implementing technological innovations that are ready/mature enough to enhance specific organization processes or transactions (micro-level change) in schools or universities. Formal to its core, the innovation diffusion model requires over-specialized laborers (gatekeepers, champions) (Rogers 2002, p. 332) assigned to smaller, less adaptive organization "spaces," bounding digital innovation teamwork in a market model frame. Formal innovation is expensive and slow getting done too.

\subsubsection{Getting Digital Innovation Experiments Done: Developing Digital Innovation Teams}

We have explained that complex adaptive system is an open and dynamic whole composed of a large number of parts operating in unsteady or constant-flux conditions, each of which behaves according to some rule or energy that relates it interactively to other parts as an open system but is not predictable as an incompressible system (Cilliers 2000). At the digital innovation team level, these networks get the work of innovation done across more open organizations. That work is often driven by tensions about the future of the organization by people who respond with an experiment (pilot, trial, research). When we understand schools and universities as complex adaptive systems, we consider relational dynamics among people in their most creative, adaptive contexts (Arena and Uhl-Bein 2018) within less formal organizations. Emerging from chaos theory, complex adaptive systems 
... exist when 'parts' of their relational networks are capable of learning, using rules that they themselves evolve... usually emerging from what is effectively a decentralized...process of co-design. (Maguire et al. 2006; Kowch 2018)

Individuals in most innovation teams get work done within relational networks spanning usual organizational boundaries. This goes beyond 'who you know' thinking by accepting that systems and structures do work in education organizations, but that the skills and talent needed to conceptualize deep innovation requires specific patterns and connections of people in a changing institutional ecosystem. Unlike formal leaders, this researcher finds that most informal leaders are unaware of individuals' influences, say, as leaders in the nonlinear "doing" and leading of their innovation work (Gereluk et al. 2016). In concert with complexity theory, this is because a change by one part of the ecosystem can result in disproportionate changes elsewhere (Capra 2002). Our research finds repeatedly that relational networks in education systems can thrive with reciprocal, shared (distributed) influence, not power-over, so that power is shared among these networks with high-capacity, decentralized patterns or clusters find autonomy and freedom in less formal self-direction during both large school (Kowch 2005) and university (Kowch 2016) innovation design and deployments.

Only leaders who are equipped to handle a complex, rapidly changing environment can implement the reforms that lead to sustained improvement. (Levin and Fullan 2008, p. 292)

Leading change as an informal leader means going beyond adopting change theory models to create change in schools and universities (Cabrera and Cabrera 2019). From a recent collection of systems thinking theory in Springer's major reference work, Learning, Design and Technology (Spector et al. 2020), section editor Kowch found a clear trend among educational technology scholars, proving that innovation leaders today trend toward more informal systems thinking about education processes to lead technology-involved systemic change (Kowch 2019). Informal systems thinking leaders do lead change differently. Compared to formal leaders who apply systems theory to solve input-process-output-feedback type problems, informal leaders experiment and build from tensions to alter what a school or university does (process), and how it impacts an ecosystem (products, outputs) as a whole. For example, most formal IT leaders in 75 school districts were found to adopt cloud technologies to ease cost pressures (Holwoka 2018), whereas some less formal IT leader teams created private clouds to ease tensions and risks arising from teacher security concerns. Later in this chapter, we explain how to create and lead highcapacity adaptive innovation teams.

Systems thinking affords leaders a method for aligning how we think about our organization process and outcomes within the context of a wider ecosystem involving individual and collective action within and beyond 'institutional' boundaries.

The real world works in systems - complex networks of many interacting variables. . . systems thinking is the field of study that attempts to understand how to think better about real-world systems and the real-world problems we face. (Cabrera and Cabrera 2019)

Beyond the scope of this chapter, specific concepts and tactics for digitization innovation teams (networks) and leaders enacting informal organization level change 
can be found in Conceptualizing the Essential Qualities of Complex Adaptive Leadership: Networks That Organize (Kowch 2013a). In sum, a high-capacity or highly capable network organization such as an innovation network reaches its goals when each member exhibits the following seven characteristics: (1) managing complex tasks, (2) generating answers to new problems, (3) rising above selfinterest, (4) relating as part of a cohesive network, (5) understanding clear roles, (6) acting with clear values, professional values, and (7) generating new information when necessary. The dynamics of high-capacity network teams depend on the following five characteristics: (1) relation types (i.e., technical, political, social, informational), (2) actors change over time,; (3) resonances (predatory, competitive, symbiotic) among patterns of people, (4) attractors that motivate cohesion and action, and (5) aggregate capacity to organize interests and set goals (p. 170). Network structures are analyzed and designed using modified social and policy network algorithms (Kowch 2003, 2018) using computer network analyses. Critical network features are (1) centrality, (2) density, and (3) clusters. Attractors are also important qualities of generative or self-empowering networks (Hazy and UhlBien 2015). Manifest in network members, attractors draw people with skills and knowledge (and fewer department formal boundaries) to coalesce as networks for problem-solving.

Innovation leaders who are attracted to lead informal organizations (like digital innovation teams) create these more autonomous network teams from interested, right-knowledge-for-the-problem people attracted to participate to solve a problem or to experiment, then they disband. See Towards Leading Diverse, Smarter and More Adaptable Organizations That Learn (Kowch 2015) for more information.

Another unique feature of complex adaptive network teams, schools, or university collective is their capability to transform by developing a new purpose, process, and outcome from previous ones, dynamically (Goldstein et al. 2010). This holistic transformation is called emergence.

Now that we have explored the kind of leadership (informal) that creates space for innovation teams to experiment and thrive, along with organizations or "structures" that allow for innovations to change the organization itself, we are ready for a model to help build, lead, and experiment with digital innovation teams so that the organization can transform from those digital innovations.

\subsubsection{Identifying the Cusp of Change on Our Way to Organization Transformation: A Critical Moment for Innovation Team Leaders}

The real voyage of discovery consists not in seeking new lands but seeing with new eyes. (Proust 1923)

An experiment can offer the DNA for a new school or university, but as informal leaders we need to be able to-or we need the capability to-identify that experi- 
ment, among many, as organization leaders - and that's a new skill. This author has studied over 300,000 participants in large school and university system change/ innovation studies over decades, finding that the vast majority of educators maintain a formal understanding of leadership, mostly because of the intensely bureaucratic nature of our organizations and traditions.

Ecologies of innovation require constant-flux conditions and open innovation conditions much as schools of fish require simple rules to work together without colliding (Cilliers 2000; Chesbrough 2020). Open innovation is a general concept in harmony with complex adaptive school and university leadership thinking (Chesbrough 2020). Nonlinear and whole-system descriptions are possible and easy now with powerful computers and analytics, but leading them requires whole-system innovation perspectives of real and deep change where generative tensions inside the organization (school, university) are drivers within robust relational networks of people interested in changing the process and product of education (Goldstein et al. 2010; Kowch 2019). A great research team with a relational leader is a good example of such a collegial, effective school staff as is a university 'skunkworks' team. Inside-out and community-connected experimentation, supported by formal leaders but influenced by networks of individuals from these soft structures, can lead to novel experiments offering a new DNA for a school activity, and these can be amplified and recombined in the complex system as it adapts. A completely new organization can emerge. Figure 9.2 shows the integration of diffusion innovation thinking in Stage 2 and 3 so that innovation diffuses throughout the ecosystem, not just as work or supervisor responsibilities aimed at 'change'.

The concept of emergence is equivalent to what some educators call 'transformation' as a caterpillar turns to a butterfly (Capra 2002; Stacey 2001). This staged development model for complex adaptive organization evolution depends on an experiment or set of experiments (i.e., digital innovations) "at the cusp of change"

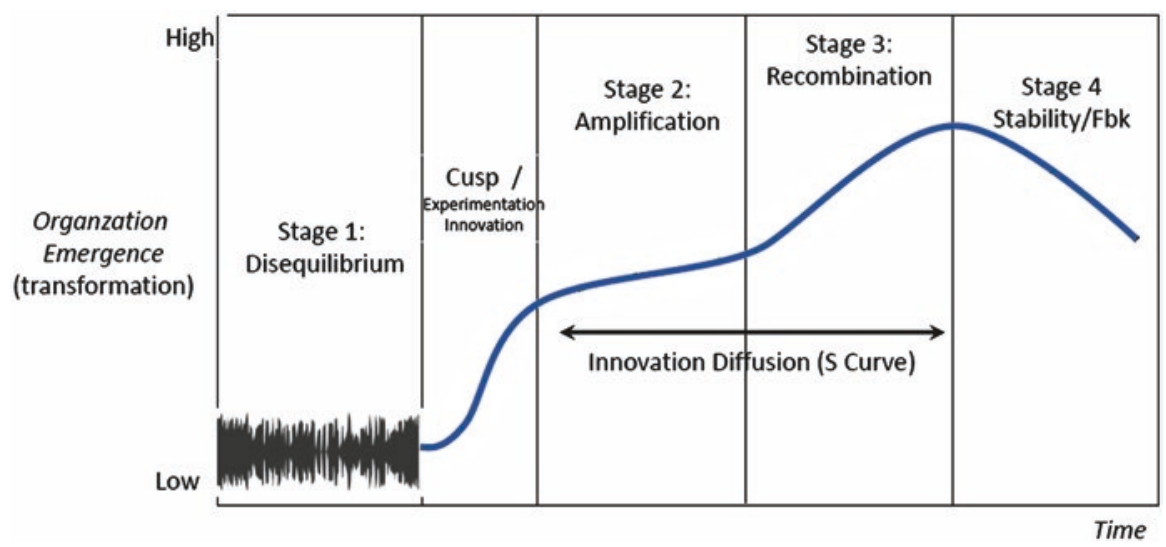

Fig. 9.2 Organizations doing the wrong things for the outcomes they imagine know that they are Stages of Organization Emergence (transformation) in a Complex, Innovating School or University Over Time 
(Goldstein et al. 2010) that change the process, product, and ideal of a school or university. The concept also lessens the separation of individuals from organizations during innovation because a relational network of people collaborates to experiment and find the DNA for a new organization (school, university), often with digital technologies (Ito 2018). Moving university leadership and organization theory forward, we should conceptualize transformation as emergence and this will free us from the old, linear (piecemeal change) mentality brought by years of technology 'adoption' thinking, for example.

A good example of emergence (transformation) was found in our research study of a school where enrolments were down, staff churn was high, and funding was limited (Gereluk et al. 2016; Kowch 2013). Faced with declining enrolments, staff turnover, and funding shortfalls, the superintendent discovered that the community in the school's ecosystem grieved about the loss of a first national language. Seeing that as a binding value and as a generative tension, that leader worked with teachers, parents, and external funders to reimagine a language curriculum with new technologies and to shift the school's purpose toward learning "around" the lost culture and language. The result was a well-funded industry-school partnership, less turnover, and full enrolment - true emergence (Kowch and Gereluk 2013).

Organization emergence (transformation) occurs in four phases (Table 9.1): (1) disequilibrium, (2) amplification, (3) recombination, and (4) feedback and relative stabilization (Goldstein et al. 2010, p. 82).

Against the backdrop of huge formal bureaucracies in education that are often unaware that they are in a state of diseqeuilibrium, emergence depends on digital innovation experiments "at the cusp of change" developed by smaller, more autonomous parts of networked organizations led by informal leaders described in this chapter. Those are the seeds for true transformations with digitization. Next, we explore guides for leading those teams.

\subsubsection{Leading Learning Organization Transformation/ Emergence with Digital Innovations: A Guide for Leaders}

We have created a guide for leading education organization emergence as this way of thinking evolves for practical use. Emerging (transforming) schools and universities have four essential qualities: (1) diversity and redundancy among members, (2) experimentation, (3) intricate networks of relations, and (4) innovations conferring new adaptive possibilities (Goldstein et al. 2010). Also conceptualized by Cilliers (2000) as ecologies of innovation, complex organizations are (1) diverse, (2) experiment-prone, (3) interdependent systems connected by interactive networks, (4) laden with innovation and new functionalities, and (5) always experiencing critical tensions and periods of instability. Because complex adaptive networks are incompressible, these networked teams are more than the reduced sum of their parts: 
Table 9.1 The characteristics of digital innovation team leaders in each stage of emergence (transformation)

\begin{tabular}{|c|c|c|}
\hline $\begin{array}{l}\text { Stage of } \\
\text { emergence } \\
\text { (transformation) }\end{array}$ & Stage characteristics & Digital innovation leader actions \\
\hline $\begin{array}{l}\text { Stage } 1 \\
\text { Disequilibrium }\end{array}$ & $\begin{array}{l}\text { Top-down structures cause instability } \\
\text { and generative tensions. Intentional } \\
\text { or planned 'jolts' move people to see } \\
\text { new purposes compared to existing } \\
\text { purposes. Left untended, the systems } \\
\text { can evolve into chaos (not good). }\end{array}$ & $\begin{array}{l}\text { Learn informal, network organization } \\
\text { and leadership concepts. Imagine } \\
\text { informal trials within existing } \\
\text { bureaucratic contexts (pilots). } \\
\text { Employees and leaders are perturbed } \\
\text { about the direction of the } \\
\text { organization. }\end{array}$ \\
\hline Cusp of change & $\begin{array}{l}\text { Informal networks, inclusive of } \\
\text { leaders are newly attracted to a new } \\
\text { purpose for the organization. } \\
\text { Generative tensions abound, leaders } \\
\text { empower risk and experimentation so } \\
\text { that new products and processes can } \\
\text { be tested. Successful experiments are } \\
\text { the DNA for an emerged (different) } \\
\text { organization. Transformed. Consider } \\
\text { digital technologies in the knowledge } \\
\text { economy }\end{array}$ & $\begin{array}{l}\text { Generative leadership begins. } \\
\text { Recognize network tensions. } \\
\text { Co-design high-capacity } \\
\text { interdisciplinary (learning, } \\
\text { instruction design, IT, finance, } \\
\text { policy) network teams. Empower risk } \\
\text { and innovation. Identify new } \\
\text { attractors/purposes held by the } \\
\text { networks. Resource experiments. } \\
\text { Seek new processes and products. } \\
\text { Avoid linear technology adoption } \\
\text { processes (champions, technologies } \\
\text { 'off the shelf'). }\end{array}$ \\
\hline $\begin{array}{l}\text { Stage } 2 \\
\text { Amplification }\end{array}$ & $\begin{array}{l}\text { Experiments have resolved } \\
\text { organization tensions. Move to } \\
\text { implementing the innovation } \\
\text { (experiment). Possibly reconfigure } \\
\text { key experiment network members to } \\
\text { lead innovation diffusion and } \\
\text { scale-up. Formal organization } \\
\text { concepts work well. }\end{array}$ & $\begin{array}{l}\text { Innovation adoption. Experiment } \\
\text { leadership networks disband, } \\
\text { resources are reallocated to implement } \\
\text { experiments and innovation. } \\
\text { Innovation diffusion occurs. } \\
\text { Incremental change leadership, } \\
\text { systemic change leadership. New } \\
\text { partners and interdisciplinary teams } \\
\text { are resourced to institutionalize } \\
\text { innovation diffusion (Rogers 2003). } \\
\text { Ecosystem should offer new value. } \\
\text { Design-based thinking. Implement } \\
\text { research to track value accrual. }\end{array}$ \\
\hline $\begin{array}{l}\text { Stage } 3 \\
\text { Recombination }\end{array}$ & $\begin{array}{l}\text { Institutionalize new processes and } \\
\text { products in more traditional ways. } \\
\text { System inertia is overcome. } \\
\text { Reaggregations and recombination/ } \\
\text { reorganization and policy } \\
\text { development for innovation-based } \\
\text { organization process result in new } \\
\text { organization 'units.' }\end{array}$ & $\begin{array}{l}\text { Reorganization. Identify novel } \\
\text { structures emerging. Maintain } \\
\text { informal organization and leadership, } \\
\text { consider entrepreneurial activity and } \\
\text { social impacts, value continuous } \\
\text { improvement and reform. }\end{array}$ \\
\hline $\begin{array}{l}\text { Stage } 4 \text { Institute } \\
\text { stabilizing } \\
\text { feedback }\end{array}$ & $\begin{array}{l}\text { Informal organization systems are } \\
\text { stabilizing. Self-reinforcing feedback } \\
\text { strengthens structures. External } \\
\text { feedback anchors researched/ } \\
\text { measured success. }\end{array}$ & $\begin{array}{l}\text { Planning: Prepare for disequilibrium } \\
\text { as the changing ecosystem around the } \\
\text { organization offers new purposes and } \\
\text { tensions for the organization. Avoid } \\
\text { formalizing everything. }\end{array}$ \\
\hline
\end{tabular}

${ }^{a}$ Adapted from Goldstein et al. (2010), Hazy and Uhl-Bein (2015), and Arena and Uhl-Bein (2018) 
When carbon, oxygen and hydrogen atoms bond in certain ways to form sugar, the resulting compound has a sweet taste threat is not in any of the separate atoms themselves. (Capra 2002)

Just as sweetness is an emergent property of sugar, process and product change is an emergent property in a complex adaptive organization. The challenge for informal digital innovation leaders in this context is to be able to identify the stages of emergence, to allocate energy/resources for experimentation (and risk), and to recognize attractors or tensions among employees. A diverse digital innovation team can design and test new experiments, noticing experiments that could put the entire organization "cusp" of transformation because they contain a new process and product DNA (Goldstein et al. 2010; Kowch 2018; Donaldson 2019). When complex adaptive teams experimented to find new processes and products with a new purpose in mind, they transformed their colleges. This is far beyond linear, incremental change afforded by teams adopting digital technology, and this is emergence-genuine transformation from innovations created by innovation team networks. Table 9.1 explains the work leaders should do at each stage of emergence.

Digitization is the technological transfer of information (flows) and tasks to a computer, allowing digital transformation when an organization changes due to an increase in IT (Chanias and Hess 2016). Digital maturity describes what an organization has already achieved in terms of changing products or processes while developing a meta-ability for leading the change process (p. 4). Recently, educational technology scholars have found that digital maturity depends on understanding and managing continuous change that helps to better facilitate organizational transformation (Ifenthaler and Egloffstein 2020). For informal education organization leaders, digitization means developing leaders and organizations for optimal digital maturity. That work is a function of strategic asset development (digital intensity) and leadership (management, vision, governance) (Chanias \& Hess, p. 6) we discuss here as leadership and organization.

Emergent universities such as the University of Phoenix have used these more formal leadership approaches to transform themselves (Hughes 2006); however, most schools and universities retain formal inertia with linear 'app adoption' mindsets for localized change (Hargreaves and Shirley 2012). The same has been found from researching college leadership teams (Donaldson 2019). So leading digital innovation well will matter more at the dawn of Big Data, Analytics, AI, and robots (Seiler et al. 2019). Scholars warn that ecosystem-driven generative tensions could shape well-made or very poor learning organizations with short futures (Kowch 2003, 2018).

In sum, leaders in adaptable relational innovation team-based networks need to be aware of new leadership approaches that allow people to bring their knowledge and skills transformation challenges as they are co-developed. This means recognizing critical experiments and digital innovations that have the DNA for a new education organization (school, university) with new ideas, processes, and products - a different future. It also means taking digital innovations, proven by testing, forward across the university ecosystem, not just for use within the organization's present 
boundaries, and to diffuse and amplify the innovation as the whole organization transforms. This work is far from adopting a widget to create a better output or budget line.

By way of a summary for the chapter, Table 9.2 offers a guideline for practicing innovation network leaders in less formal organizations (school districts, schools, universities, faculties, departments) so that there is a complementary "space" for "cusp of change" digital innovation diffusion across the institution. In Phase 1, leaders simply need to be aware that they need to create networks from across the ecosystem to address organization tensions (challenges) of importance. In Phase 2, leaders amplify those innovations so that the new processes and products become the focus of the entire university or school. Of course, if the organization and leadership work has not been right up to this point, there will be no adaptive space in the organization so the innovation will stall.

One good example of emergence is Netflix. Beginning with an organization's purpose to create and rent entertainment DVDs, a group of employees eventually noticed that the Internet would allow digital transmission of movies online. They experimented to find a way out of obsolescence because no mature digital innovation encompassing re-organizing and distribution existed. They developed a new purpose to build their capacity for streaming movies. Experiments yielded new vendor contracts and production companies driven by that tension among employees attracted to a new goal: provision for streamed entertainment eventually leading to cloud-based streaming entertainment reshaping the industry. The company emerged (Goldstein et al. 2010; Pant and Yu 2018).

Table 9.2 A two-phase model for leading innovation-driven digital transformation in adaptive schools and universities

Phase I: Leader network

Awareness and experimentation

Digital innovation leadership for transforming schools and universities: characteristics

1. Develop an ability and mindset to identify or create tensions and attractions that generate digitization experiments by teams resolved to solve those organization level problems.

2. Develop diverse, redundant interdisciplinary (high capacity) distributed network teams to get work done. In doing this, the innovation network will define new purposes and processes within this informal organization for a different future.

3. Facilitate and resource/empower risk and experimentation with technologies in core purpose contexts.

4. Validate experiments (rapid prototype, research).

Phase II: Amplify

innovations across the ecosystem
5. Enact innovation diffusion by expanding the experiment across the organization and its ecosystem. Strive for digital maturity. Use system thinking to lead systemic change.

6. Dissipate the leadership networks, institutionalize the new organization as an informal organization with policy-making.

7. Watch for new generative tensions and experiments. 


\subsubsection{Concluding Remarks}

In this chapter, we argued that learning organization transformation is more likely in a future with less formal leadership and structuration (organization) of the work we do in education.

First, we showed that formal leaders restrict interaction and innovation by separating people from the challenges and innovations that might change schools and universities. Formal organizations similarly restrict the "space" for digital innovations by creating rules and vertical, functional hierarchies limiting interaction among people with different knowledge and skill sets across the school or university ecosystem. Even when transformative digital innovations emerge, they have difficulty lasting because the organization is not adaptable enough.

Next, we explored less formal leadership that can connect knowledge across "job" boundaries with a wider vision for networked innovation experiments using social and values-oriented guidance. We then explained high-capacity network team structures or patterns that decrease the separation of people (in jobs) from innovation work spanning the institution. That allows for experiments driven by the digital innovation team to identify the process and product DNA for a different school/ university.

We close with guidelines for leading these teams and digital innovation through the stages of development that a university follows when transforming (emerging) so that a new university emerges.

Further research is required to help education systems identify tensions, develop new purposes, and mitigate formal epistemologies in the context of digitization. In addition, we need research helping us understand the attractors that draw innovators to a team, and the resource issues that come with ecosystem-level change leadership and more research done to describe and interpret sudden or disruptive change with digital innovation so that we can map intentional vs. chaotic emergence from digital innovation. Education systems are changing-but our leaders wear the suits of another era and work to maintain a house from the last century this limits experimentation and the scalability possible through digital innovation. With mindsets considering complex adaptive ecologies of education, our new leaders are learning these skills now - will the universities and schools of tomorrow be ready for them?

\section{References}

Arena, M., \& Uhl-Bein, M. (2018). Leadership for organizational adaptability: A theoretical synthesis and integrative framework. The Leadership Quarterly, 29, 89-104.

Barabasi, A. (2003). Linked: How everything is connected to everything else and what it means. New York: Plume Publishing.

Bertalanffy, L. (1968). General system theory. New York: George Braziller. 
Bodily, R., Leary, H., \& West, R. (2019). Research trends in instructional design and technology journals. British Journal of Educational Technology, 50(1), 64-79.

Cabrera D., Cabrera L. (2019) What is Systems Thinking? In: Spector M., Lockee B., Childress M. (Eds.), Learning, Design, and Technology. Cham: Springer. https://doi. org/10.1007/978-3-319-17727-4_100-1.

Capra, F. (1997). The web of life. New York: Anchor Books.

Capra, F. (2002). The hidden connections: A science for sustainable living. New York: HarperCollins.

Carlsen, A., Clegg, S., Pitsis, T., \& Mortensen, T. (2020). From ideas of power to the powering of ideas in organizations: Reflections from Follett and Foucault. European Management Journal. https://doi.org/10.1016/j.emj.2020.03.006.

Chanias, S., \& Hess, T. (2016). How digital are we? Maturity models for the assessment of a company's status in the digital transformation. Management Report, 2, 1-14. Ludwig-MaximiliansUniversitat Munchen.

Chesbrough, H. (2020). Open Innovation results: Going beyond the hype and getting down to business. Oxford: Oxford University Press.

Child, J., \& McGrath, R. G. (2001). Organizations unfettered: Organizational form in an information-intensive economy. The Academy of Management Journal, 44(6), 1135-1149.

Christensen, C., Horn, M., \& Johnson, W. (2008). Disrupting class. New York: McGraw Hill.

Cilliers, P. (2000). Complexity and Postmodernism: Understanding Complex Systems. New York NY: Routledge.

Clegg, S., Harris, M., \& Hopfl, H. (2011). Managing Modernity. Oxford: Oxford University Press.

Cuban, L. (2001). Oversold and underused: Computers in the classroom. Cambridge, MA: Harvard University Press.

Donaldson, B. (2019). Towards leading adaptable colleges: A description of the potential for experimentation in three British Columbia colleges. Unpublished Doctoral dissertation, University of Calgary. Canada.

Downing, D. (2018). Leadership and technology adoption decisions: Case study research. Unpublished Doctoral dissertation, University of Calgary. Canada.

Fullan, M. (2015). The new meaning of educational change (5th ed.). New York: Teachers College Press.

Fullan, M., \& Kirtman, L. (2016). Leadership: Key competencies for whole-system change. Bloomington: Solution Tree Press.

Gereluk, D., Kowch, E., \& Thompson, M. (2016). The Alberta public charter school system: A system of secret gardens. Canada Education, 56(2), 21-29.

Gharajedagahi, J. (2011). Systems Thinking: Managing Chaos and Complexity. Burlington, MA. Elsevier.

Goldstein, J., Hazy, J., \& Lichtenstein, B. (2010). Complexity and the nexus of leadership. New York: Palgrave.

Granovetter, M. (1973). The strength of weak ties. American Journal of Sociology, 6(6), $1360-1380$.

Greenfield, T. (1984). The decline and fall of science in educational administration. Interchange, 17(2), 57-80.

Greenwald, H. P. (2008). Organizations: Management without control. Los Angeles: Sage.

Gronn, P. (2002). Distributed leadership. In K. Leithwood \& P. Hallinger (Eds.), Second international handbook of educational leadership administration, part 2 (pp. 653-697). Boston: Kluwer.

Gu, J., Wang, G., Liu, H., Song, D., \& He, C. (2018). Linking authoritarian leadership to employee creativity: The influences of leader-member exchange, team identification and power distance. Chinese Management Studies, 12(2), 384-406. 
Hallinger, P., \& Heck, R. (2002). What do you call people with vision? The role of vision mission and goals in school leadership and improvement. In K. Leithwood \& P. Hullinger (Eds.), Second international handbook of educational leadership and administration (Vol. I, pp. 90-40). Boston: Kluwer.

Hargreaves, A., \& Fink, D. (2006). Sustainable leadership. San Francisco: Jossey-Bass.

Hargreaves, A. \& Shirley, D. (2012). The global fourth way. Thousand Oaks, CA: Corwin.

Harris, A. (2008). Distributed school leadership. London: Routledge.

Hazy, J., \& Uhl-Bien, M. (2015). Towards operationalizing complexity leadership: How generative, administrative and community-building leadership practices enact organizational outcomes. Leadership, 11(2), 79-104.

Holowka, P. (2018). IT Leadership and cloud computing adoption in Western Canadian K-12 school districts. Unpublished Doctoral Dissertation, University of Calgary. Canada.

Hughes, M. D. (2006). Process of legitimation. The University of Phoenix and its institutional environment. Unpublished doctoral dissertation. University of Arizona.

Ifenthaler, D. (2017). Are higher education institutions prepared for learning analytics? TechTrends, 61(4), 366-371. https://doi.org/10.1007/s11528-016-0154-0.

Ifenthaler, D., \& Egloffstein, M. (2020). Development and implementation of a maturity model of digital transformation. TechTrends, 64(2), 302-309.

Ito, J. (2018). The practice of change. Unpublished Doctoral dissertation, Keio University, Japan.

Kowch, E. (2005). The knowledge network: A fundamentally new (relational) approach to knowledge management \& the study of dependent organizations. Journal of Knowledge Management Practice, 6, 13-37.

Kowch, E. (2009). New capabilities for cyber charter school leadership: An emerging imperative for integrating Educational Technology and Educational Leadership knowledge. Tech Trends Special Edition, 53(1), 40-49.

Kowch, E. (Ed.). (2013). Educational technology leadership. [Special Issue]. TechTrends, 57, 5.

Kowch, E. (2013a). Conceptualizing the essential qualities of complex adaptive leadership: Networks that organize and learn. International Journal of Complexity in Leadership and Management, 2(3), 162-184.

Kowch, E. (2013b). Wither thee, Educational Technology? Suggesting a critical expansion of our epistemology for emerging leaders. TechTrends, 57(5), 11-27. London: Sage.

Kowch, E. (2015). Towards leading diverse, smarter and more adaptable organizations that learn. In J. Lewis, A. Green, \& D. Surry (Eds.), Technology as a tool for diversity leadership: Implementation and future implications (pp. 11-35). Hershey: IGI Global.

Kowch, E. G. (2003). Policy networks and communities: Neo Institutional policy development for nebulous, pressing pan institutional issues. Unpublished Doctoral Dissertation. University of Saskatchewan, Saskatoon.

Kowch, E. G. (2016). Surviving the next generation of organizations - as Leaders. In N. Rushby \& D. Surry (Eds.), The Wiley Handbook of Learning Technology (pp. 484-507). Oxford: Wiley.

Kowch, E. (2018). A new paradigm for teaching, leading and learning in participatory learning environments. In B. Shapiro (Ed.), Actions of their own to learn (pp. 225-251). London: Sense Publishers.

Kowch, E. (2018a). Designing and leading learning ecosystems: Challenges and opportunities. TechTrends, 62(1), 132-134.

Kowch, E. G. (Section Ed.). (2019). Introduction to systems thinking and change. In M. Spector, B. Lockee, \& M. Childress (Eds.), Learning, design, and technology. Cham: Springer. https:// doi.org/10.1007/978-3-319-17727-4_133-1

Kowch, E. G. (2020). Ethics to prepare educators for professional service robots in classrooms. In Proceedings of the IEEE 2019 International Joint Conference on Information, Media and Engineering (IJCIME), December, Osaka, Japan. 478-484. https://doi.org/10.1109/ IJCIME49369.2019.00102. 
Kowch, E., \& Gereluk, D. (2013). The capacity, adaptability and impact of the Alberta Public School Charter System. Report to the Alberta Association of Public Charter Schools (TAAPCS). Edmonton. 211 pp. TAAPCS.

Leithwood, K., \& Jantzi, D. (2005). A review of transformational school leadership research: 1996-2005. Leadership and Policy in Schools, 4(3), 177-199. https://doi. org/10.1080/15700760500244769.

Levin, B., \& Fullan, M. (2008). Learning about system renewal. Educational Management and Leadership, 36, 289-304. https://doi.org/10.1177/1741143207087778.

Licht, A. H., Tasiopoulou, E., \& Wastiau, P. (2017). Open book of educational innovation. Brussels: European Schoolnet.

Lord, R. G., \& Brown, D. J. (2001). Leadership, values, and subordinate self-concepts. The Leadership Quarterly, 12(2), 133-152.

Maguire, S., McKelvey, B., Mirabeau, L., \& Oxtas, N. (2006). Complexity science and organization studies. In S. Clegg et al. (Eds.), Organization Studies (2nd ed., pp. 164-2014). Oxford: Oxford University Press.

Marion, R., \& Uhl-Bein, M. (2007). Paradigmatic influence and leadership. In C. s. 1. theory (Ed.), Hazy, Goldstein \& Lichtenstein (pp. 144-158). Mansfield: ISCE Publishing.

Marion, R., \& Uhl-Bien, M. (2001). Leadership in complex organizations. The Leadership Quarterly, 12(4), 389-418.

Mitchell, C., \& Sackney, L. (2011). Profound improvement (2nd ed.). New York: Routledge.

OECD. (2016). Innovating education and educating for innovation: The power of digital technologies and skills. Paris: OECD Publishing. https://doi.org/10.1787/9789264265097-en.

Pant, V., \& Yu, E. (2018). Conceptual modeling to support the "Larger Goal" pivot - An example from Netflix. In R. Buchmann, D. Karagiannis, \& M. Kirikova (Eds.), The practice of Enterprise Modeling. PoEM 2018. Lecture Notes in Business Information Processing (p. 335). Cham: Springer.

Proust, M. (1923). The Prisoner, (C. K. Moncrief, Trans.). 5, 2.

Reigeluth, C. M., \& Duffy, F. (2008). The AECT FutureMinds initiative: Transforming America's school systems. Educational Technology, May, 45-49.

Rogers, E. M. (1962). The diffusion of innovations. New York: Sweet Beagle Books.

Rogers, E. (2002). The nature of technology transfer. Science Communication, 23(3), 323-341.

Rogers, E. M. (2003). Diffusion of innovations (5th ed.). New York: Free Press.

Schwandt, D. R., \& Szabla, D. (2007). Systems leadership: Co evolution or mutual evolution towards complexity? In Hazy, J., Goldstein, J., \& Lichtenstein, B. (Eds.), Complex systems leadership theory (pp. 35-59). Mansfield, ISCE Publishing.

Seiler, L., Kuhnel, M., Ifenthaler, D., \& Honal, A. (2019). Utilizing learning analytics to support study success: Reflections on current and empirical findings. In L. Seiler, D. Ifenthaler, \& A. Honal (Eds.), Utilizing learning analytics to support study success (pp. 27-36). Cham: Springer.

Senge, P. M., Cambron-McCabe, N. H., \& Lucas, T. (2000). Schools that learn: A fifth discipline fieldbookfor educators, parents, and everyone who cares about education. New York: Random House.

Sergiovanni, T. (1989). The leadership needed for quality schooling. In T. Sergiovanni \& J. Moore (Eds.), Schooling for tomorrow. Boston: Allyn and Bacon.

Spector, J. M., \& Ma, S. (2019). Inquiry and critical thinking skills for the next generation: From artificial intelligence back to human intelligence. Smart Learning Environments, 6, 8.

Spector, M., Lockee, B., \& Childress, M. (2020). Learning, design and technology: An international compendium of theory, research and practice. Cham: Springer.

Stacey, R. M. (Ed.). (2001). Complex responsive process in organizations: Learning and knowledge creation. New York: Routledge.

Uhl-Bein, M., Marion, R., \& McKelvey, B. (2007). Complexity leadership theory. The Leadership Quarterly, 18, 298-318. 
Visvizi, A., Lytras, M. D., \& Daniela, L. (Eds.). (2018). The future of innovation and technology in education: Policies and practices for teaching and learning excellence. London: Emerald Publishing.

West, R., \& Borup, J. (2014). An analysis of a decade of research in 10 instructional design and technology journals. British Journal of Educational Technology, 45(4), 545-556.

Yukl, G. (1994). Leadership in organizations: Third Edition. Englewood Cliffs: Prentice-Hall.

Zhai, Y., Ding, Y., \& Wang, F. (2018). Measuring the diffusion of an innovation: A citation analysis. Journal of the Association for Information Science \& Technology, 69(3), 368-379. https:// doi-org.ezproxy.lib.ucalgary.ca/10.1002/asi.23898.

Open Access This chapter is licensed under the terms of the Creative Commons Attribution 4.0 International License (http://creativecommons.org/licenses/by/4.0/), which permits use, sharing, adaptation, distribution and reproduction in any medium or format, as long as you give appropriate credit to the original author(s) and the source, provide a link to the Creative Commons license and indicate if changes were made.

The images or other third party material in this chapter are included in the chapter's Creative Commons license, unless indicated otherwise in a credit line to the material. If material is not included in the chapter's Creative Commons license and your intended use is not permitted by statutory regulation or exceeds the permitted use, you will need to obtain permission directly from the copyright holder.

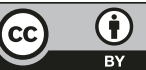

